\title{
Investigation of Wing, Fuselage and Tail Design Parameters in Boeing and Airbus Aircraft
}

\author{
Seyhun Durmuş* \\ *Balikesir University, Edremit School of Civil Avation, Balikesir, Turkey, (ORCID: 0000-0002-1409-7355), drmsyhn@gmail.com
}

(First received 2 November 2021 and in final form 25 December 2021)

(DOI: 10.31590/ejosat.1017730)

ATIF/REFERENCE: Durmus, S., (2021). Investigation of Wing, Fuselage and Tail Design Parameters in Boeing and Airbus Aircraft. European Journal of Science and Technology, (31), 699-705.

\begin{abstract}
The study aims to examine the wing, fuselage and tail design parameters of Airbus and Boeing aircraft and to reveal the design criteria for the sizing of large commercial jets. Tin the study, the design and sizing data of 11 Airbus models and 14 Boeing models were compiled. The number of abreast seats, maximum seats, fuselage length, fuselage width, fineness ratio, tail section length, cockpit length and cargo compartment length are the main parameters studied about the fuselage design. Wing area, wingspan, aspect ratio, mean aerodynamic chord (MAC), taper ratio, dihedral angle, quarter chord sweep angle, and winglet lengths are the main parameters studied about the wing design. The area, span, aspect ratio, taper ratio, and quarter chord sweep angle of vertical and horizontal tail are the main parameters studied about the tail design. As a result of the study, exceptional designs and average design criteria for Airbus and Boeing aircraft have been revealed with the help of charts presented. In addition, the obtained linear correlations reveal that the MAC has about 0.14 times the wingspan and about 1.168 times the average chord length.
\end{abstract}

Keywords: Aircraft design, Wing design, Tail design, Boeing, Airbus.

\section{Boeing ve Airbus Uçaklarında Kanat, Gövde ve Kuyruk Tasarım Parametrelerinin İncelenmesi}

$\ddot{O} \mathbf{z}$

Çalışma, Airbus ve Boeing uçaklarının kanat gövde ve kuyruk tasarım parametrelerini incelemeyi ve bu tip büyük ticari yolcu uçakların tasarımına yönelik tasarım kriterlerini ortaya koymayı amaçlamaktadır. Çalışmada 11 Airbus modeli ve 14 Boeing modeli için tasarım ve boyutlandırma verileri derlenmiştir. Yan yana koltuk sayısı, maksimum koltuk sayısı, gövde uzunluğu, gövde genişliği, incelik oranı, kuyruk bölümü uzunluğu, kokpit uzunluğu ve kargo bölümünün uzunluğu gövde tasarımı hakkında incelenen parametrelerdir. Kanat alanı, kanat açıklığı, ortalama kiriş uzunluğu, ortalama aerodinamik kirişler MAC, en-boy oranı, koniklik oranı, çeyrek veter süpürme açısı, dihedral açısı ve winglet uzunlukları kanat tasarımı hakkında çalışılan temel parametrelerdir. Dikey ve yatay kuyruk alanı, açıklık, en-boy oranı, koniklik oranı ve çeyrek veter süpürme açısı, kuyruk tasarımı hakkında çalışılan temel unsurlardır. Çalışma sonucunda sunulan grafikler yardımıyla Airbus ve Boeing uçakları için istisnai tasarımlar ve ortalama tasarım kriterleri ortaya konmuştur. Ek olarak, doğrusal korelasyonlar, MAC'nin kanat açıklığının yaklaşık 0.14 katı ve ortalama kiriş uzunluğunun yaklaşık 1.168 katı olduğunu ortaya koymaktadır.

Anahtar Kelimeler: Uçak tasarımı, Kanat tasarımı, Kuyruk tasarımı, Boeing, Airbus. 


\section{Introduction}

Since the 1990s, the competition between Airbus and Boeing has led to the formation of a duopoly in the large commercial aircraft market. Airbus has strengthened as a pan-European consortium, while Boeing has strengthened by adding McDonnell Douglas to its structure. Fokker and BAE Systems were forced to withdraw from the market because they could not compete with Airbus and Boeing [1]. Boeing became the world's top aircraft manufacturer in 2006 with 1,044 orders against Airbus's 824 orders [2]. Due to the sales momentum that achieved by Airbus thanks to the A320neo family, and the problems experienced by Boeing with the Boeing 737 MAX, the A320 family eventually surpassed the Boeing 737 to become the best-selling aircraft in 2017 [3]. Statistics conducted in 2019 showed that a total of 11394 Boeing aircraft and a total of 10137 Airbus aircraft were in service [4]. Conceptual aircraft design consists of important stages such as weight estimation, initial sizing, and engine selection [5]. In present study, fuselage, wing and tail sizing and design criteria were examined without touching on weight and thrust issues. Parameters such as the number of abreast seats, maximum seats, fuselage length, fuselage width, finesse ratio, length of tail section, length of cockpit and length of cargo compartment were examined in fuselage design and sizing. Parameters such as the wing area, wingspan, mean aerodynamic chord (MAC), aspect ratio, taper ratio, quarter chord sweep angle, dihedral angle, and length of the winglets were examined in the wing design and sizing. Parameters such as the area, span, aspect ratio, taper ratio, and quarter chord sweep angle of vertical and horizontal tail were examined in the empennage design and sizing. Raymer [5] proposed an approach based on the power correlation between aircraft mass and fuselage length for estimating fuselage lengths using the maximum takeoff gross mass. The fuselage size determined by the volume required for the maximum number of passengers and the maximum amount of cargo, and both can be selected in various combinations to give the maximum payload capacity [6]. In his study of commercial passenger aircraft, Morichon [7] found that the lengths of cargo compartment are 0.45 times the lengths of the fuselage. Roskam [8] calculated the fuselage nose, the length of the cockpit, the cabin at the back and the tail boom as a function of the fuselage diameter. Kruger et al. [9] claims that the low fineness of the fuselage design, reduces the drag on aircraft configuration, which will save between $5 \%$ and $16 \%$ on fuel consumption. The volume required for the cabin can be calculated from the recommended average density values for cargo and baggage from the Torenbeek [10] database. Schmitt and Golnick [11] argued that increasing the fuselage diameter of aircraft beyond 8 or 9 -abreast will increase the exterior circular body surface. The mean aerodynamic chord (MAC) is a parameter that is referenced in aerodynamics and stability calculations in preliminary airplane design. Yates [12] made the first calculations of the average aerodynamic chord, which is still used today. Nicolai and Carichner [13] have noted that the wing is located on the fuselage in such a way that its center of gravity is about $30 \%$ of the wing's MAC. Vogeltanz [14] has developed a method and software that accurately calculates the MAC even on elliptical wings. Sforza [15] has proposed a direct calculation method that can predict the lift to drag ratio with the help of MAC. Although Redeker and Wichmann [16] suggest that the forward sweep angle causes a more stable laminar boundary layer, the critical Mach number is increased by sweep, regardless of whether this is with the help of a forward sweep or a rear sweep [17]. Although increasing the wing aspect ratio allows for higher lift-to-drag ratios, commercial jets often have wings with relatively low aspect ratios due to higher deflections, which can cause flutter problems in the wings [18]. Nicolosi et al. [19] conducted a study on the relationship of aircraft directional stability and vertical tail sizing. Yass [20] claimed that increasing the aspect ratio of the horizontal tail enhances both the damping ability and rolling static stability and reduces the damping ability in the spiral mode. Obert [21] has argued that a high aspect ratio in the tail design has a negative (albeit relatively small) effect on tail weight, and a high taper ratio can cause premature tip stall. There are various studies in the literature about alternative concept designs in commercial passenger aircraft. Taking Airbus 320 and Boeing 737 family aircraft as a reference, Prandtlplane provides higher aerodynamic efficiency by improving the payload capacity by $50 \%$ [22]. Elmendorp et al. [23] conducted a comparative study of key performance indicator of the canard, three surface, and Prandtl aircraft with respect to conventional designs. The D8 doublebubble aircraft with a complex, non-round fuselage shape is an airliner aircraft that demonstrates the potential to reduce fuel consumption by $25-30 \%$ compared to the Boeing 737-800 [24]. The efficiency of the $\mathrm{N}+3$, a hybrid wing fuselage design, achieves $45 \%$ lower fuel burn than the Boeing 737-800 due to the improved propulsion system and the supposed structural improvements [25]. In the current study, it is aimed to determine the wing, fuselage and tail design parameters of Boeing and Airbus and to find both average design characteristics and to identify the models with exceptional designs by examining the models in comparative charts.

\section{Material and Method}

In this study, design and sizing data such as the number of abreast seats, maximum seats, fuselage length, fuselage width, finesse ratio, length of tail section, length of cockpit and length of cargo compartment, wing area, wingspan, aspect ratio, mean aerodynamic chords, taper ratio, dihedral angle, quarter chord sweep angle, and length of the winglet, vertical and horizontal tail area, tail span, tail aspect ratio, tail taper ratio, and quarter chord tail sweep angle of 11 Airbus models and 14 Boeing models were compiled. Aircraft sizing and design data are obtained from manufacturers' web pages and from the book of Jane's all the world's aircraft [26-28].

Below are a few important parameters in aircraft design and the equations for how they are calculated. Fineness ratio is the ratio of the length of fuselage to the aircraft width, as shown in Eq. 1.

$$
\text { Fineness ratio }=\frac{\text { Fuselage length }}{\text { Width }}
$$

The aspect ratio is the ratio of the wingspan to the average chord length, as shown in Eq. 2.

$$
\text { Aspect ratio }=\frac{\text { Wingspan }}{\text { Average Chord Length }}=\frac{\mathrm{b}}{\bar{c}}
$$

The taper ratio is the ratio of the tip chord length to the root chord length, as shown in Eq. 3.

$$
\text { Taper ratio }(\lambda)=\frac{\text { Tip Chord }}{\text { Root Chord }}=\frac{C_{t}}{C_{r}}
$$

Mean aerodynamic chord (MAC) is an important parameter since the position of center of gravity of an aircraft is measured relative to the MAC. MAC can be calculated using the root chord and taper ratio, as shown in Eq. 4 [9].

$$
\mathrm{MAC}=\frac{2}{3} C_{r} \frac{1+\lambda+\lambda^{2}}{1+\lambda}
$$

The studied models of Boeing and Airbus are presented in Table 1, where they are included in the first flight years. 
Table 1. Boeing and Airbus models examined with the first flight years.

\begin{tabular}{|l|l|l|l|l|l|}
\hline \multicolumn{3}{|c}{ Boeing Aircraft } & \multicolumn{4}{c|}{ Airbus Aircraft } \\
\hline & Type- Model & Year & & Type- Model & Year \\
\hline 1 & B707-320C & 1962 & 1 & A300-600R & 1974 \\
\hline 2 & B737-200 & 1967 & 2 & A310-300 & 1983 \\
\hline 3 & B737-400 & 1967 & 3 & A320-200 & 1988 \\
\hline 4 & B737-500 & 1967 & 4 & A321-100 & 1993 \\
\hline 5 & B727-200Adv & 1970 & 5 & A340-200 & 1993 \\
\hline 6 & B757-200 & 1982 & 6 & A330-300 & 1994 \\
\hline 7 & B767-200 & 1982 & 7 & A319-100 & 1995 \\
\hline 8 & B767-300 & 1982 & 8 & A330-200 & 1998 \\
\hline 9 & B747-400 & 1988 & 9 & A340-500 & 2002 \\
\hline 10 & B777-200ER & 1995 & 10 & A340-600 & 2002 \\
\hline 11 & B737-700 & 1997 & 11 & A380-800 & 2004 \\
\hline 12 & B737-800 & 1998 & & & \\
\hline 13 & B717-200 & 1999 & & & \\
\hline 14 & B757-300 & 1999 & & & \\
\hline
\end{tabular}

\section{Results and Discussion}

In the study, the results of the analysis related to the design and sizing of the fuselage, then the wing and finally, the tail are shown in the charts. From the point of view of the abreast seats, the 6, 7,9 and 10 arrangements will be seen. 6- and 9-abreast are slightly more than others. Fig. 1 shows the distribution of abreast seats and total seats on Boeing and Airbus aircraft. The 7 seat abreast is seen as a Boeing 767. Airbus and Boeing's doubledecker aircraft (Boeing 747, A380), also called Super Jumbo have 10 abreast seats. Also, Boeing 777-200 model has 10 abreast seats. Although there is no direct relationship between the number of abreast seats and the total number of seats, it can be said in general that as the number of abreast seats increases the total number of seats increases.

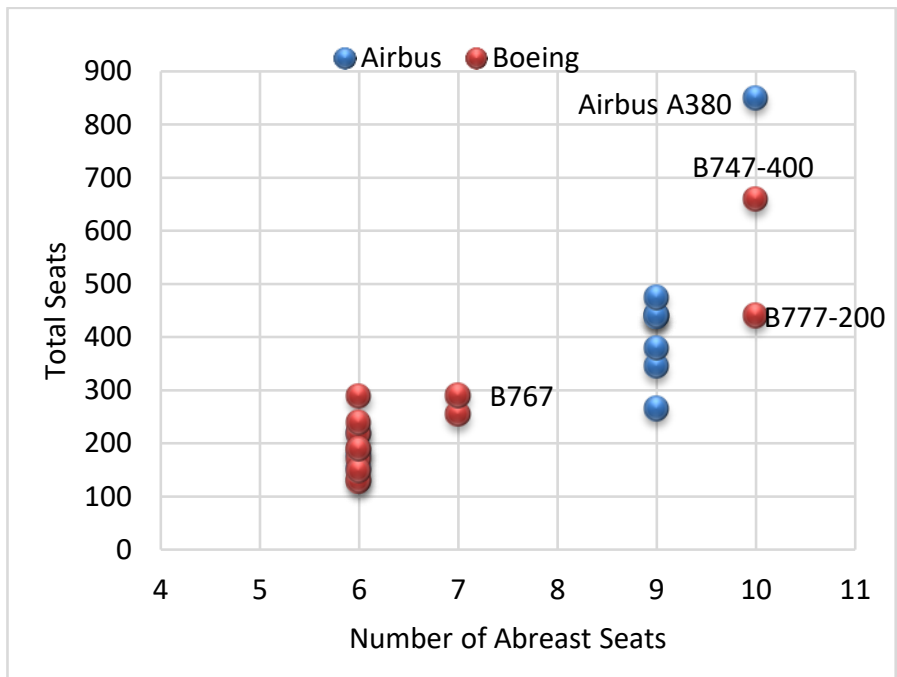

Figure 1. The distribution of abreast seats and total seats in Boeing and Airbus aircraft

Boeing's double-decker aircraft-Boeing 747400 model and the Boeing 737-200 model have the smallest cockpit length.
However, the double-decker aircraft of Airbus-A380-800 has the longest cockpit length $(4.66 \mathrm{~m})$. Fig. 2 shows the distribution of cockpit length and tail length on Boeing and Airbus aircraft. The cockpit lengths rages from $3.6 \mathrm{~m}$ to $4.2 \mathrm{~m}$. In terms of tail lengths, Airbus A340-600, and double-decker jumbo jets (Boeing 747, A380) have the longest tail sections.

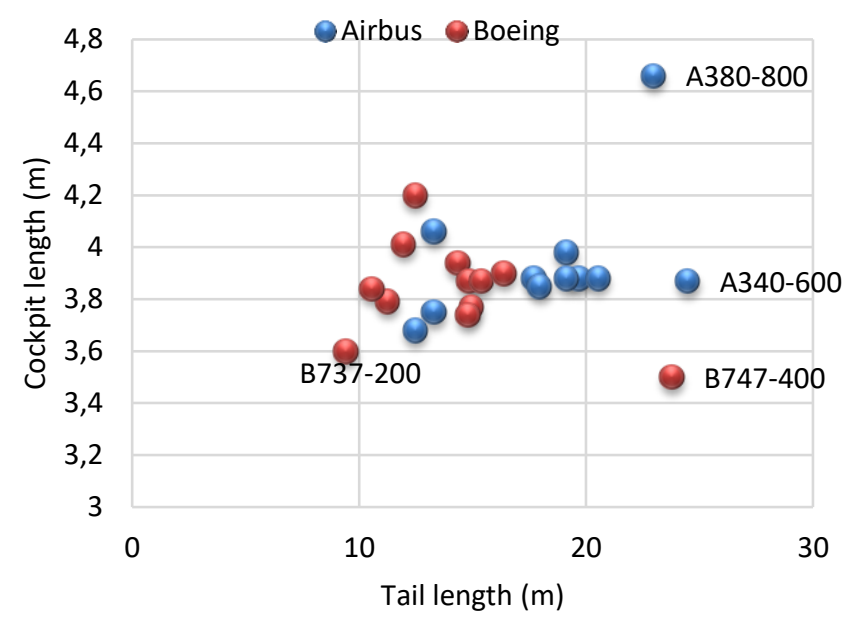

Figure 2. Distribution of cockpit length and tail length in Boeing and Airbus aircraft

Just like tail lengths, the fuselage length of the A340-600 and double-decker jumbo jets (Boeing 747, A380) is the largest. Fig. 3 shows the distribution of fineness ratio and fuselage length in Boeing and Airbus aircraft. Fineness ratio is a factor that affects the total drag of the aircraft. While the fineness ratio of the aircraft varies between 6 and 14, and it is mainly clustered between the 8 12. The lowest fineness ratio in Boeing belongs to B737-200 model and in Airbus aircraft it belongs to the A319-100 model. The highest fineness ratio in all belongs to the B737-300 model.

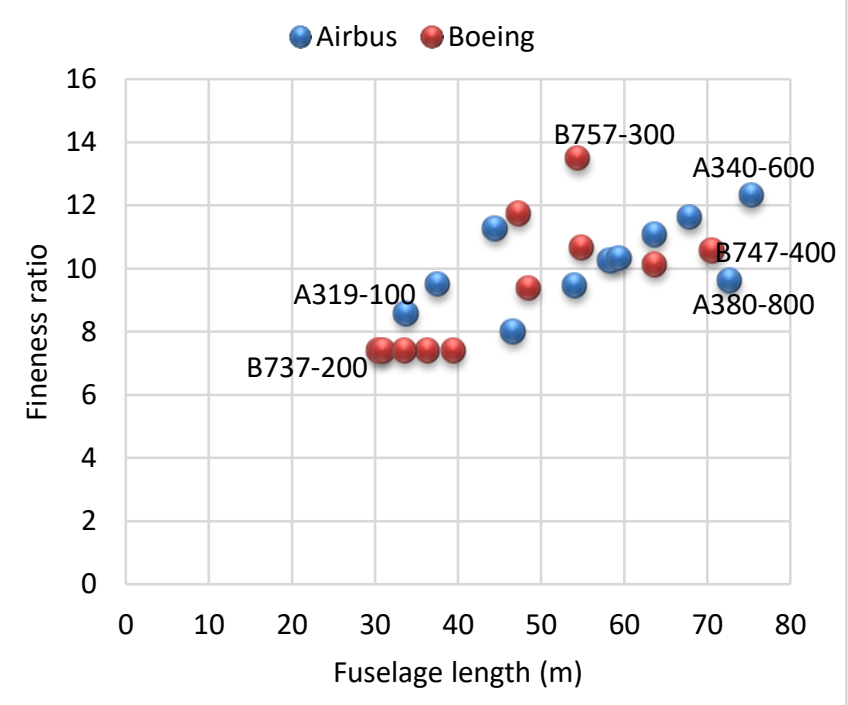

Figure 3. Distribution of the fineness ratio and fuselage length in Boeing and Airbus aircraft 
Fig. 4 shows the ratio of the length of cargo compartment to the total length of Boeing and Airbus aircraft. It can be said that the length of the cargo compartment varies between $35 \%$ and $55 \%$ of the total length of aircraft. Narrow-body aircraft (A310-300, B737-500) have a shorter cargo compartment length, while widebody Airbus A340-600, Boeing 767-300 and A380-900 models have a relatively longer cargo compartment.

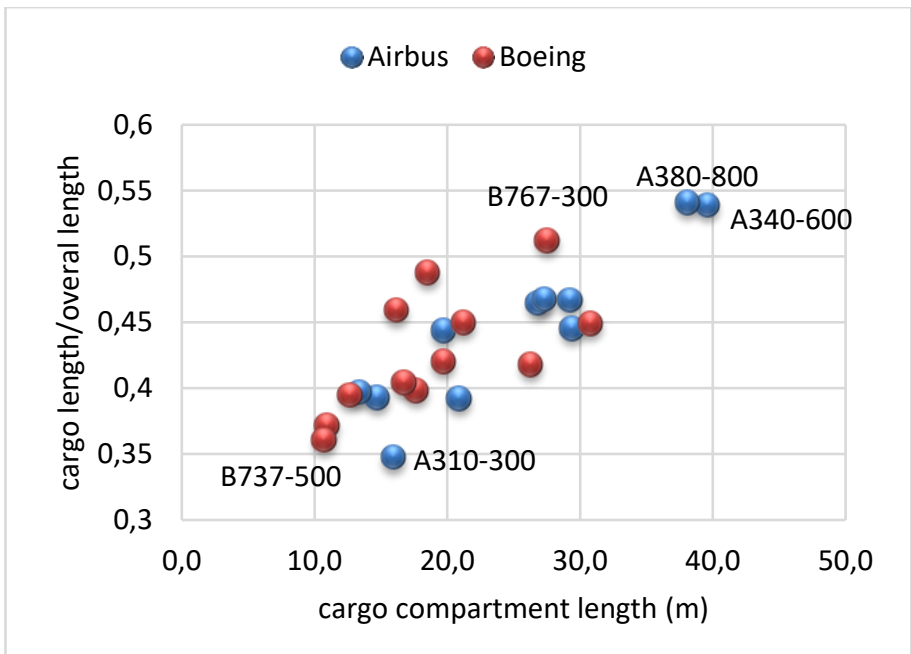

Figure 4. Ratio of length of cargo compartment to the total length of the Boeing and Airbus aircraft

In Fig. 5, the correlation between the average chord length and mean aerodynamics chord (MAC) in Boeing and Airbus aircraft is given by the trendline equation, where $\mathrm{R}^{2}$ value of 0.99 . As shown in Eq. 5, mean aerodynamics chord (MAC) the corresponds to 1.168 of the average chord lengths $(\bar{c})$ of a commercial jet.

\section{$\mathrm{MAC} \cong 1.168 \bar{c}$}

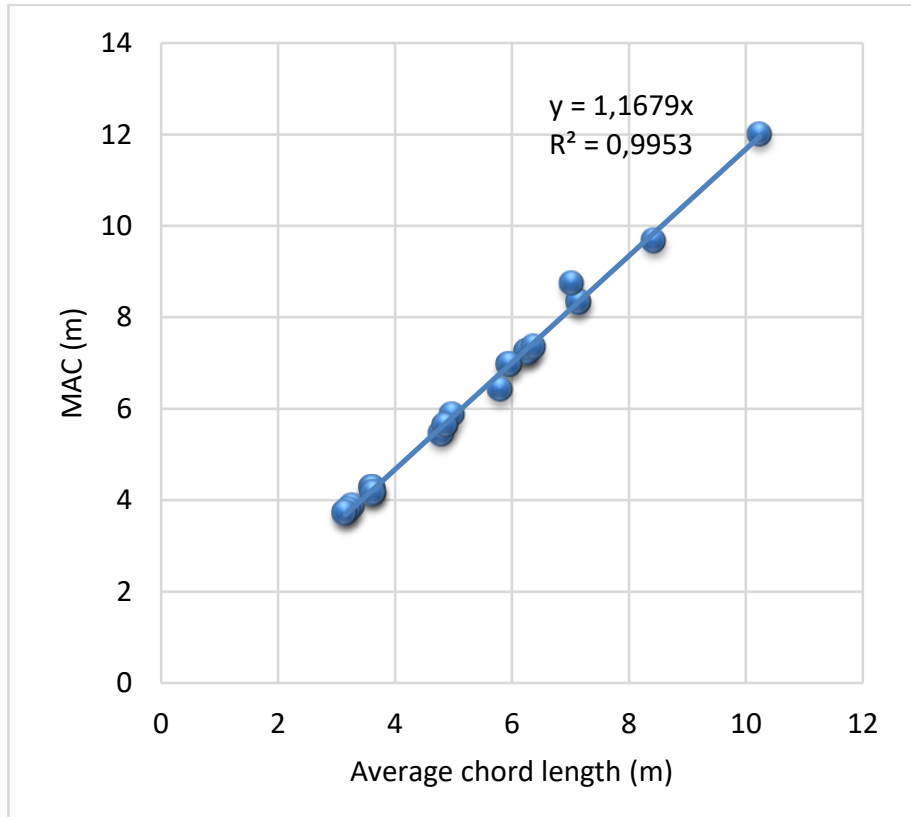

Figure 5. Relationship between average chord length and $M A C$ in Boeing and Airbus aircraft
In Fig. 6, the correlation between mean aerodynamics chord (MAC) and wingspan on Boeing and Airbus aircraft is given by the trendline equation, where $\mathrm{R}^{2}$ vale is about 0.92. As a percentage, the average aerodynamic chord on airplanes corresponds to about $14 \%$ of wingspan (b), as given in Eq. 6 .

$\mathrm{MAC} \cong 0.14 \mathrm{~b}$

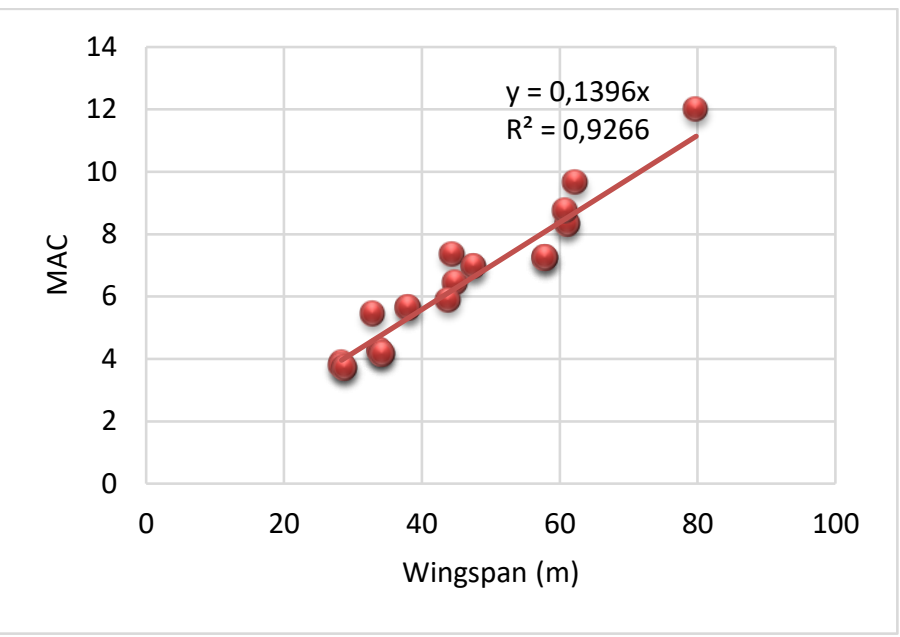

Figure 6. Relationship between wingspan and MAC in Boeing and Airbus aircraft

Fig. 7 shows the distribution of quarter chord sweep angle and dihedral angle in Boeing and Airbus aircraft. The dihedral angle is a design factor in lateral stability, which increases the stability of the aircraft. In general, the dihedral angle is between $5^{\circ}-7^{\circ}$ in commercial jets. The wing sweep angle is a design factor that delays the turbulence at high speeds, that is, it increases the critical Mach number. Looking at Fig. 7, the first thing that stands out is that Boeing uses higher dihedral angles in its wings than Airbus. In addition, Boeing uses sweep angles ranging from $25^{\circ}$ to $37.5^{\circ}$ on its wings, while Airbus uses a narrow scale, ranging from $25^{\circ}$ to $31.1^{\circ}$ sweep angle.

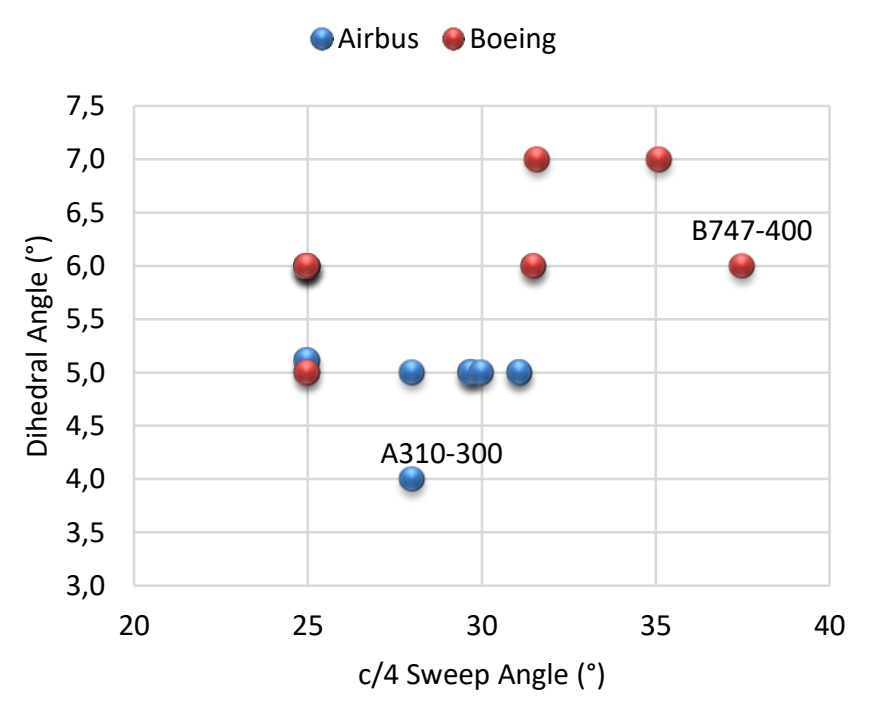

Figure 7. Distribution of the quarter-chord sweep angle and dihedral angle in Boeing and Airbus aircraft 
Winglets are add-ons added to the wingtip to minimize the negative effects of wingtip vortices. Fig. 8 shows the ratio of winglet length to wingspan length of Boeing and Airbus aircraft. The lengths of winglet are usually between $3 \%$ and $5 \%$ of the wingspan. Exceptionally high winglets are used on Boeing 737800 model. So much so that Airbus's Jumbo jet A380 uses a 2.83 $\mathrm{m}$ long winglet, while the Boeing 737-800 uses a $2.44 \mathrm{~m}$ long winglet.

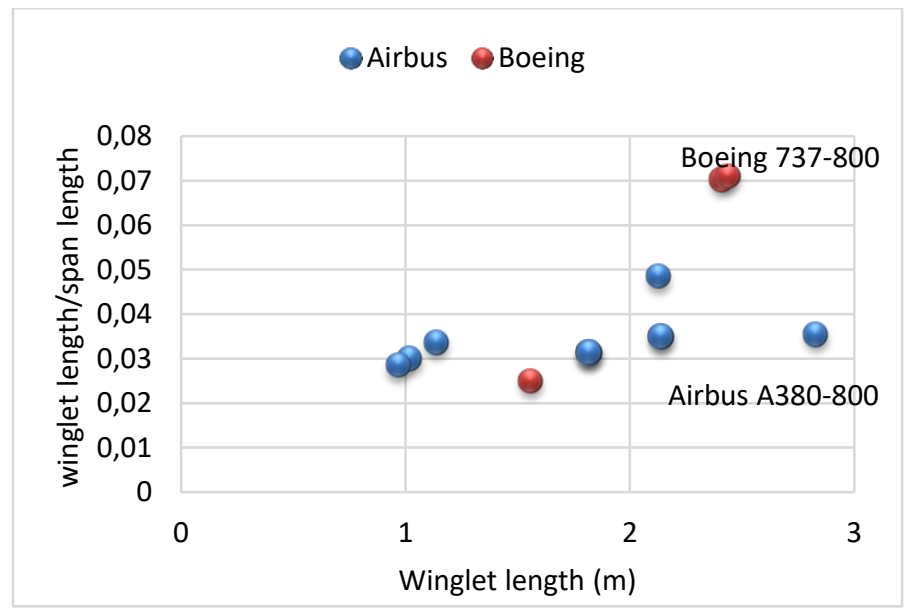

Figure 8. Ratio of winglet length to the wingspan length of the Boeing and Airbus aircraft

Fig. 9 shows the distribution of wing aspect ratio (AR) and vertical tail AR-horizontal tail AR in Boeing and Airbus aircraft. The wingspan ratio in the commercial passenger jets studied ranged from 7 to 10 , while the vertical tail aspect ratio was generally between 1.5 and 2, in horizontal tail aspect ratio was mostly accumulated between 4.50 and 5.20. Exceptionally, the horizontal tail of the Boeing 77 and the horizontal tail of the Boeing 737-800 aircraft have high AR values.

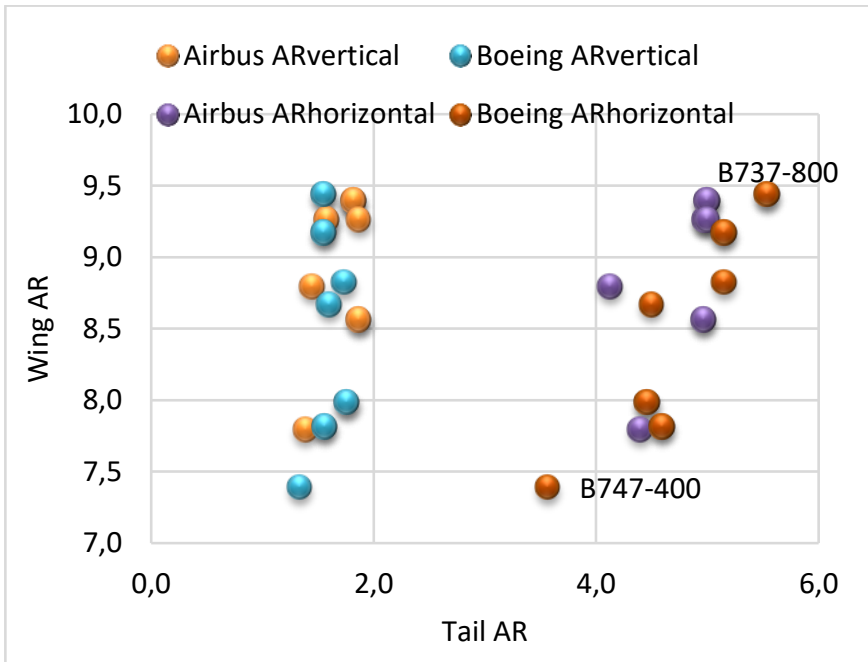

Figure 9. Distribution of wing AR and vertical tail $A R$ horizontal tail AR in Boeing and Airbus aircraft
The design parameter that reduces the effect of vortices on the wingtips and improves the lift distribution is the wing taper factor. Fig. 10 shows the distribution of the wing taper ratio and horizontal tail and vertical tail taper ratio in Boeing and Airbus aircraft. As the taper ratio of both the vertical tail and horizontal tail is close to each other, detailed representations in the form of Boeing and Airbus have not been made. Taper ratio on the aircraft wings is clustered between 0.2-0.3; while on aircraft tails it is clustered between 0.2 and 0.4 . It is possible to mention a wider scale taper ratio in the vertical tail than in the horizontal tail.

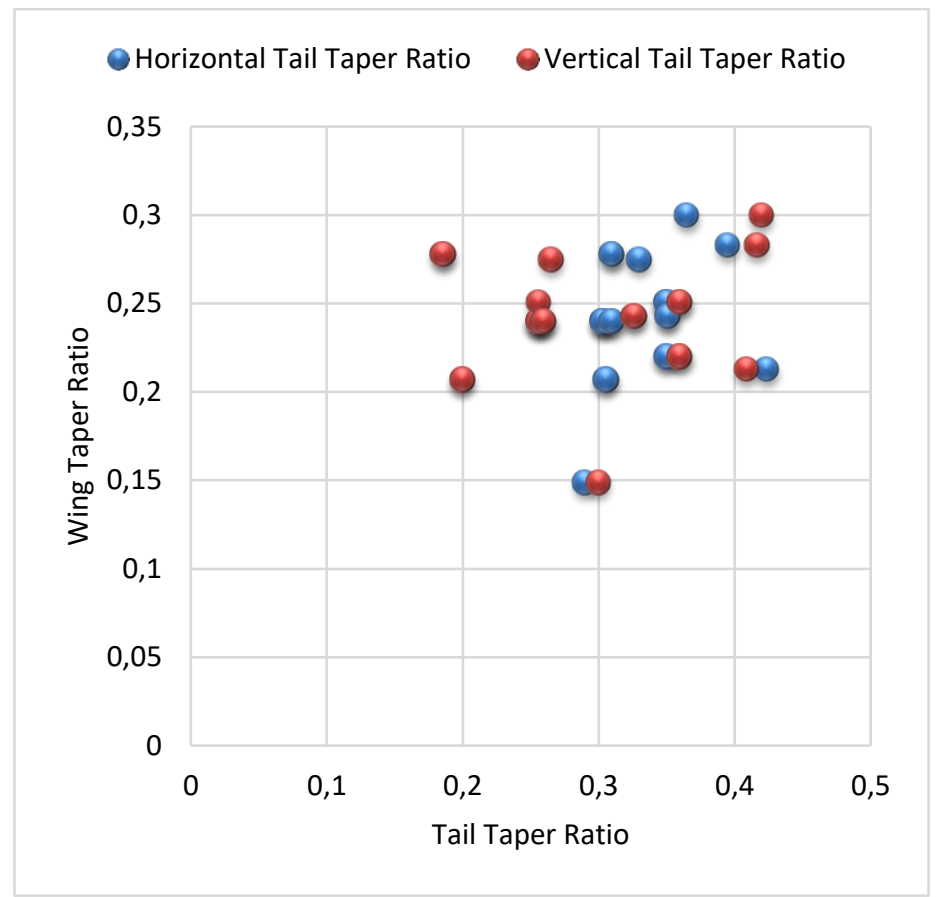

Figure 10. Wing taper ratio and horizontal tail-vertical tail taper ratio distribution on the Boeing and Airbus aircraft

Fig. 11 shows the distribution of horizontal tail chord sweep angle and vertical tail quarter chord sweep angle vs wing quarter chord sweep angle in Boeing and Airbus aircraft. The vertical tail has a sweep angle on a larger scale ranging from $30^{\circ}$ to $46^{\circ}$, and the horizontal tail has a sweep angle on a narrower scale ranging from $27.5^{\circ}$ to $36^{\circ}$

The lack of a study in the literature that considers the fuselage wing and tail design parameters of the vast majority of Boeing and Airbus aircraft models together makes this study valuable. In the figures (Fig.1-Fig. 11) presented in the present study, the average design values of Airbus and Boeing aircraft models with different design criteria were revealed. The correlations given in the Eq.5 and Eq.6, in commercial passenger aircraft, the approximate value of the MAC value can be calculated with the help of both the wingspan and the average chord length. 


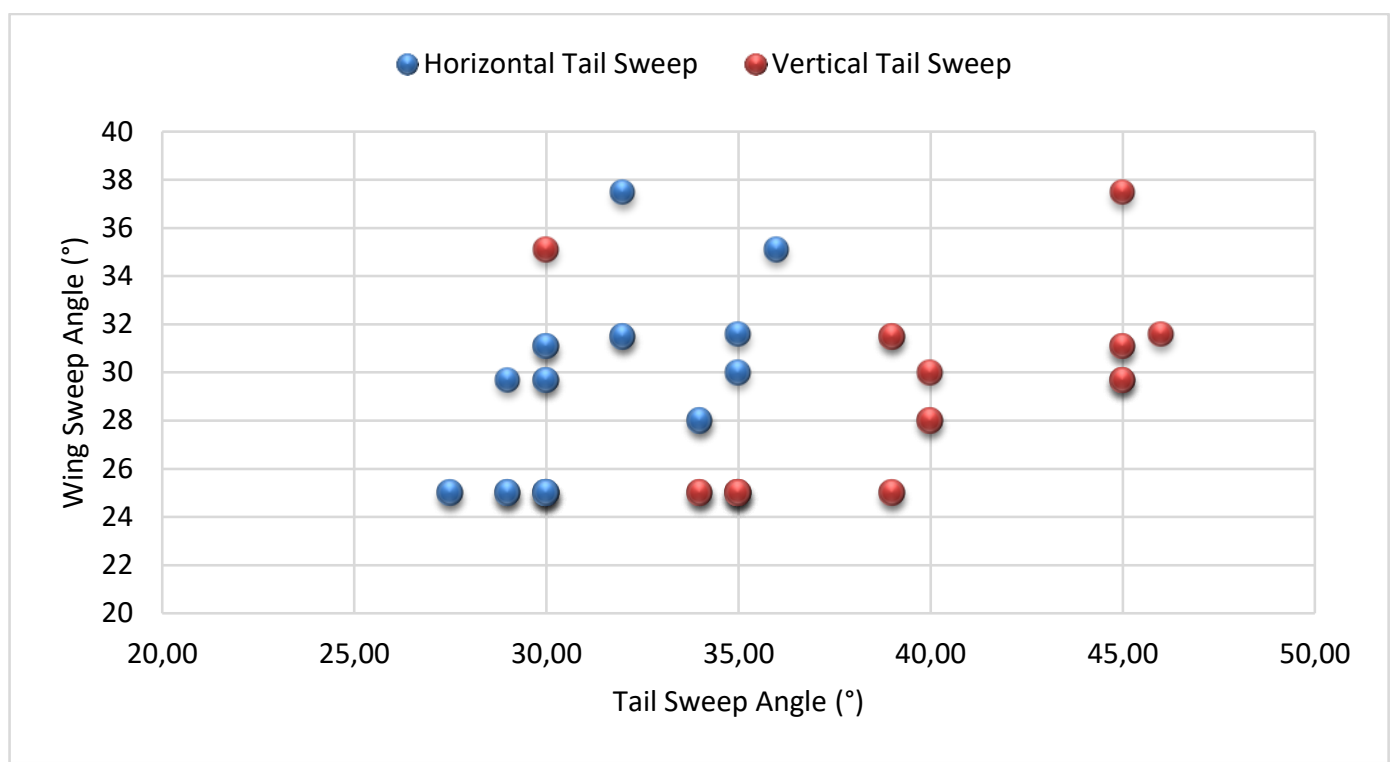

Figure 11. Distribution of wing's quarter-chord sweep angle and horizontal tail-vertical tail's quarter-chord sweep angle in Boeing and Airbus aircraft

\section{Conclusions and Recommendations}

In present study, the fuselage, wing, and tail design parameters of 11 Airbus models and 14 Boeing models were compiled. As a result, exceptional designs and average design criteria were revealed with the help of presented charts. The fineness ratio of aircraft is from 6-14, and it has accumulated mainly from $8-12$. It can be said that the length of the cargo compartment varies between $35 \%$ and $55 \%$ of the total length of aircraft. The average cargo compartment length is about $45 \%$ of fuselage length. In general, the dihedral angle is between the $5^{\circ}$ $7^{\circ}$ and Boeing uses higher dihedral angles than Airbus. In addition, Boeing uses wide sweep angles ranging from $25^{\circ}$ to $37.5^{\circ}$ on the main wings, while Airbus uses a narrow scale sweep angle ranging from $25^{\circ}$ to $31.1^{\circ}$. Winglet lengths are usually between $3 \%$ and $5 \%$ of the wingspan. Exceptionally, high winglet length is used on Boeing's 737-800 model. The aspect ratio of the wings varies between 7 and 10, the aspect ratio of the vertical tail accumulated between 1.5 and 2, and aspect ratio of the horizontal tail mostly accumulated between 4.50 and 5.20. The taper ratio on the aircraft wings is mostly between $0.2-0.3$ and it is mostly between 0.2 and 0.4 in the tail. The taper ratio of vertical tail has a wider range comparing to the horizontal tail. Similarly, the vertical tail has a sweep angle on a larger scale, ranging from 30 to 46 , while the horizontal tail has a narrower scale, ranging from 27.5 to 36 . As a result of linear correlations with high coefficient of determination- $\mathrm{R}^{2}$, it was found that the MAC has about 0.14 times the wingspan and it has about 1.168 times the average chord length.

\section{References}

[1] Newhouse, J. (2007). Boeing versus Airbus. Vintage.

[2] Petrescu, R. V., Aversa, R., Akash, B., Corchado, J., Berto, F., Apicella, A., \& Petrescu, F. I. (2017). When boeing is dreaming-a review. Journal of Aircraft and Spacecraft Technology, 1(3).

[3] Flottau, J. (2018). Airbus and Boeing ponder higher narrowbody production: after strong 2017, both manufacturers see upward pressure on rates; suppliers warn of potential bottlenecks. Aviation Week \& Space Technology.
[4] Flight Global (2019) World Airline Census 2019," Flight International.

[5] Raymer, D. (2018). Aircraft design: a conceptual approach. American Institute of Aeronautics and Astronautics, Inc

[6] Fielding, J. P. (2017). Introduction to aircraft design (Vol. 11). Cambridge University Press.

[7] Morichon, L. (2006). Selected statistics in aircraft design. Department of Automotive and Aeronautical Engineering, Hamburg University of Applied Sciences.

[8] Roskam, J. (1989). Airplane design part III: layout design of cockpit, fuselage, wing and empennage: cutaways and inboard profiles. Roskam j., airplane design: part IV, layout design of landing gear and system.

[9] Kruger, M., Huyssen, R. J., Smith, L., \& Meyer, J. P. (2016). Application of a low fineness ratio fuselage to an airliner configuration. In 54th AIAA Aerospace Sciences Meeting (p. 1282).

[10] Torenbeek, E. (2013). Advanced aircraft design: conceptual design, analysis and optimization of subsonic civil airplanes. John Wiley \& Sons.

[11] Schmitt, D., \& Gollnick, V. (2016). The Air Transport System. In Air Transport System (pp. 1-17). Springer, Vienna.

[12] Yates, A. H. (1952). Notes on the Mean Aerodynamic Chord and the Mean Aerodynamic Centre of a Wing. The Aeronautical Journal, 56(498), 461-474.

[13] Nicolai, L. M., \& Carichner, G. E. (2010). Fundamentals of aircraft and airship design, Volume 1-Aircraft Design. American Institute of Aeronautics and Astronautics.

[14] Vogeltanz, T. (2016, June). Application for calculation of mean aerodynamic chord of arbitrary wing planform. In AIP Conference Proceedings (Vol. 1738, No. 1, p. 120018). AIP Publishing LLC.

[15] Sforza, P. M. (2020). Direct Calculation of Zero-Lift Drag Coefficients and (L/D)max in Subsonic Cruise. Journal of Aircraft, 57(6).

[16] Redeker, G., \& Wichmann, G. (1991). Forward sweep-A favorable concept for a laminar flow wing. Journal of aircraft, 28(2), 97-103.

[17] Kundu, A. K. (2010). Aircraft design (Vol. 27). Cambridge University Press. 
[18] Suleman, A., Afonso, F., Vale, J., Oliveira, É., \& Lau, F. (2016). Non-linear aeroelastic analysis in the time domain of high-aspect-ratio wings: Effect of chord and taper-ratio variation. The Aeronautical Journal, 121(1235).

[19] Nicolosi, F., Ciliberti, D., Della Vecchia, P., Corcione, S., \& Cusati, V. (2017). A comprehensive review of vertical tail design. Aircraft Engineering and Aerospace Technology.

[20] Yass, M. A. (2007). Effect of Airplane Tail Aspect Ratio on Lateral-Directional Stability. Engineering and Technology Journal, 25(6).

[21] Obert, E. (2009). Aerodynamic design of transport aircraft. IOS press.

[22] Frediani, A., Cipolla, V., Salem, K. A., Binante, V., \& Scardaoni, M. P. (2019). Conceptual design of PrandtlPlane civil transport aircraft. Proceedings of the Institution of Mechanical Engineers, Part G: Journal of Aerospace Engineering, 095441001982643.

[23] Elmendorp, R. J. M., Vos, R., \& La Rocca, G. (2014). A conceptual design and analysis method for conventional and unconventional airplanes. In ICAS 2014: Proceedings of the 29th Congress of the International Council of the Aeronautical Sciences, St. Petersburg, Russia, 7-12 September 2014. International Council of Aeronautical Sciences.

[24] Yutko, B. M., Titchener, N., Courtin, C., Lieu, M., Wirsing, L., Tylko, J., ... Church, C. S. (2017). Conceptual Design of a D8 Commercial Aircraft. 17th AIAA Aviation Technology, Integration, and Operations Conference.

[25]Mody, P., Sato, S., Hall, D., De la Rosa Blanco, E., Hileman, J., \& Wen, E. (2010, July). Conceptual design of an N+3 hybrid wing body subsonic transport. In 28th AIAA Applied Aerodynamics Conference (p. 4812).

[26] Paul, J. (2005). Jane's all the world's aircraft. 20042005. Jane's Information Group Inc, Alexandria.

[27] Boeing (2021). Technical Specs. Access date: 20.09.2021 https://www.boeing.com/commercial/

[28] Airbus, S. A. S. (2021). Airbus Family Figures. Airbus. 